\title{
Theoretical considerations of post communist political elite; on focus Albania
}

\author{
Merlinda Andoni, MA \\ Lecturer, Faculty of Social Science, \\ Univeristy of Tirana, Tirana, Albania \\ Email: merlindaoco@yahoo.com
}

\begin{abstract}
This article provides literature and empirical studies review on post-communist political elite. The most debatable question is if old nomeklatura has reproduced itself and is transformed in new elite, or circulation of new blood occurs. Although post communist political elite typology is different among post communist countries, some common theoretical considerations for analyzing it are noticed. This article aims to point out that legacy of the past and accumulation of political capital coupled with the political economic marketization of post communist political elite and civil society and intelligentsia are beneficiary for a thorough understanding of the topic.
\end{abstract}

Keywords: political elite, post communism, reproduction, circulation, political capital

\section{Introduction}

"Plus ca Change " means a lot has changed, but yet everything remains the same, may be considered probably the most generalizing metaphor in terms of scholar conclusions of post-communist elite and its identity nowadays. Although it aims to study post communist political elite( after 1990s') from a theoretical point of view and provide philosophical response to questions raised in different assumptions, literature review shows that perhaps not equally, but to a certain degree, old nomenclature presence in all countries of the former communist bloc in the so-called new elite seems to be quite significant. Expressed in theoretical retoric, what prevails is the reproduction of old elite rather than its circulation. Another generalizing factor pertaining to the interest on the study of post - communist elite is the fact that large portions of researchers agree on the importance of elites as a decisive factor in smoothly overcoming transition and further consolidating of the democratic system. The character of a political system actually varies to a great extent on the type of relationship between the elites and their main features (Field et al . 1990; Higley / Burton 1998). This is particularly true in the case of transformation of the system in which elites play a key role in the set up of institutions (Kaminski / Kurczewska 1994.) As differently stated by Pareto and Marks : " Revolutions are above all, cases of elite transformation, or otherwise put- substitution of an elite by another " ( Vladimir Shlapentokh , Christopher K. Vanderpool, Boris Zusmanovich Doktorov, Croatia Dusko ; Frane Adam / Matev . Tom.ič).

The elites in general are conceived as entities that are found in a stage of self- preservation and self-protection of their interests, but always in ongoing transformation. As mentioned metaphorically by Pareto, they are not static but in a situation of slowly change "It flows on like a river, never being today what it was yesterday "(Pareto 1997/1935, 49). For this reason, it is very important to understand: what happens within elite groups? How open are they with new elites? What kind of relationship is established between them? Is there a reproduction or circulation of elites? To what extent they were part of the old nomenclature and their relationship with it today? What happens with the new bourgeoisie? What is the connection of new bourgeoisie with the positions of new political elites? How deep is the substitution / replacement of old elite with a new elite / or more precisely how deep is the phenomenon of circulation of elites? The question that arises is whether are new qualitative changes with the new elite as compared with the old one, which are its key features in comparison? Meritocratic Selection Process- based on what criteria old elite is part of the new elite? (eg education is a factor) - How strong and visible is the requirement of party membership in elite in our sample years- 1984 and 1989 ? The circulation and reproduction - to what degree has the unity and disunity of old nomenclature affected the reproduction or distribution of the 
elite nowadays? Whats the impact of conditions such as: age, gender, social and geographic origin, national composition and levels of education; Political elites and the quality of democracy - degree of their association and how they affect each other? Political elites and social background - Circulation in term of family background. Political elites with regards to functionality and importance of traditional and organic elites to the public - To what extent are the past communist elite organic and traditional / is there any movement or circulation noticed?

Literature review shows that political elites are described as positional or functional ones.Most of the authors are interested to understand the relationship between political elite and democratization, as well as the socio economic modernization of the transitional societies per se. Even though typological differences between post communist societies, types of political elites that they represent, democratic system applied are evident, common theoretical consideration through which elite can be analyzed and give answers to aforementioned questions exist. The most important of these theoretical indipendet variables are; legacies of the past and accumulation of political and institutional capital; pluralist marketization of economy and civil society and inteligencia.

\section{Legacy of the past and accumulation of political capital}

In order to understand post communist elite, researches should analyze the correlation between the influence of old nomeklatura in post communist society and it's decision making democratic process. In this perspective, there are two important theories that explain this theoretical consideration: theory of elite reproduction and theory of elite circulation.

Reproduction theory suggests that revolutionary changes have not shaped the social composition of elites. According to this theory, old nomeklatura still occupies the highest hierarchical social levels, becoming nowdays the new borgouesy. On the other hand, elite circulation theory, argues that post communist transition, above all be accompanied with the changes on the highest hierarchical levels of society. Based on this assumption, new elite is recruited with new principles on decision making positions. In each of the aforementioned theories, the main question is if circulation or reproduction as phenomenon has happened in a post communist society?

Empirical studies on the topic show that the higher the accumulation of legacy in terms of negative political and institutional capital, the bigger the level of elite reproduction itself will be (P. Nikiforos Diamandouros and F. Stephen Larrabee 1999). Unfortunately, balkanic countries, and especially Albania that has undergone an extreme communist dictatorship regime, are characterized by high levels of negative political capital accumulation. Hiperbolization of lidership cult; centralization and verticalization of power; lack of free election; high levels of corruption; problems with guaranty of human rights; problems with freedom of press, are some of the components of political capital.

Freedom House's latest report in 2014 which combines scores from three subcategories: the legal environment; the political environment; and the economic environment; shows that Albania is still a partly free country (https://www.freedomhouse.org/report/freedom-press/2013/albania\#.VLe8FNLF-Y8). Albania is listed 98th in 2014, regressing from the position held in 2013 in which it was listed 96th.

Furthermore, 2014 Transperancy International Report on Corruption, ranked Albania 110th, out of 175 countries (http://www.transparency.org/country\#ALB) . In the same logic, European Commision 2014 Albania Progress Report in terms of political criteria, reiteriate the fact that juridical and public reforms, constructive and pluralistic political dialogue, fight against corruption and organised crime, are some of the thorny issues that Albania needs to tackle immediately. More specifically the report states that:

Additional and sustained efforts will need to be fully compliant with the political criteria. In regards to democracy and the rule of law, it is essential to build on recent achievements and consolidate the reform momentum. Albania will need 
to vigorously pursue judicial and public administration reforms. The fight against corruption and organised crime needs to remain as top priority, with sustained and ongoing efforts and enforcement of legislation to fight corruption and combat all kinds of other criminal activities. The legislative framework on fundamental rights and its enforcement will have to be improved in its entirety. A more constructive political dialogue is needed for the reforms to be sustainable (https://eudelegationalbania.files.wordpress.com/2014/10/memoon-key-findings_eng.pdf)

The aforementioned reports, treat practices that are considered as contributers of "political capital", (that must be positive) which presence or absence influence the democratization consolidation process and continous transition of the society. In cases such as Albania, when negative political capital persists, it seems that regime change did not come naturally but was considered as the only solution due to historical, political and economic circumstances at the time (P. Nikiforos Diamandouros and F. Stephen Larrabee 1999).

In their article "Elite settlements and Taming of Politics", Higley and Burton argue that in such cases, transitioning to a consolidated democratic society depends on the role that new political elite accomplish. In transitional societies, political system is a byproduct of political elite activity, mentality and constructive relationship that they establish with each other (Field et a;l 1990; Higley/Burton 1998).

In countries such as Albania and most part of the Balkans (excluding here Slovenia and Croatia), even after the communist regime change, old nomeklatura still has the political power inherited fom the past (Frane Adam / Matev. Tom.ič 2002). Authors explain that, old nomeklatura survived the regime change and managed to transform in new post communist political elite , using their connections, resources and know how that they had acquired by being associated with communist political forces. This "usage" of political power is not only socio -political capital, but also economical in nature. In these conditions, when socio-political and economic power has changed only the facade, from communist to post communist elite, but not its content and substance it is obvious that the main characteristic of such transition societies is the reproduction of elite (Hankiss, 1990; Stanizzkis, 1991; Wasilewski, 1998; White and Krystanovskaya, 1998).

During regime change, while the communist party modified itself, political elite reproduction was massive, and communist economic elite have reproducted within itself also. Majority of the authors, that have conducted empirical studies, agree to a common diagnosis of the phenomenon: while broadly is pretended and assumed that the socio political and economic system has changed, the hierarchial top levels of society remains the same. In other words, the mentality and how the system in reality works have not changed. What has changed is only the manners that old nomeklatura applies to legimitate itself and its privileges. To summarize it, dominant position of such authors, is 'reproduction of political elite in post communist societies" and "very strong impact of old nomeklatura legacies". Besides that the new borgeous that has not only again the political power, but economical also. Simultaneously a new phenomenon of marketization of economy is blossoming. This 'new post communist political elite" uses political power in order to enrich itself. Next section explains the relationship between old nomeklatura and new plouralist political economic marketization of post communist society. Through theoretical considerations and refering to empirical studies the following paragraphs aim to stress the importance of yet another common characteristic via which these societies can be analyzed.

\section{Political economic marketization of post communist political elite}

For sociologists sucs as Pareto and Marx, their definition for revolution is above all the change of elite class, from an old communist elite (in our case), to a new democratic one. It is normal that in every revolution, changes are not absolute, 
which translates that part of old elite continues to hand out its expertise and contribution to the new system. The issue here is relevant to the main question at the same time, which aims to know the degree of transformation and changing of elite. The answer for this question is given from results based on empirical studies performed in post communist societies. According to these studies what happened is that officially, homegenity and domination of old regime is not visible, but old nomeklatura still retains the hold of top positions on decision-making and economic activities.

Whereas for other authors such as Linz and Stepan (1996), the circulation of elite has the highest propability to occur when the regime changes from a close totalitarian to an open one rather tha within the same system, for example from democracy to democracy, empirical studies on post communist societies bring to light different interesting facts.

A number of authors argue that while it is true that systems might formally change, the same can not be said for its political elite. In his David Stark,"Path dependence and privatization strategies in East Central Europe" analyzes the relationship between economic power relationships. According to him, the only differentiation the per se system change introduced was that of" power usage" from plan to clan in communism, to public for private in post communism regime (1992). Old nomeklatura being transformed to a new post communist political elite, "use" their resources and connections for enhacing their political economical assets. Based on this, what most authors contemplate, is that the perspective reproduction of political elite is the main characteristic of post communist societies (Dusko Sekulic and Zeljka Sporer 2002; Andrew G. Walder 2003; Hankiss, 1990; Stanizzkis, 1991; Wasilewski, 1998; White and Krystanovskaya, 1998).

As evidenced in reality, these old political elite and cadres are advantaged politically and are transformed nowdays as representatives of large corporations and successful, new entrepreneurs. Since public assets are managed from public representatives or individuals with power, elites have the enormous advantage compared with other groups of interest. Old cadres that are transformed nowdays in new post communist entrepreneurs compete in an unfair political environment with new "fresh of the boat" elite, increasing at the same time the gap between old and new elite (Dusko Sekulic and Zeljka Sporer 2002, 85-87).

Theoretically the perspective that tried to analyze the abovementioned phenomenon, of how old cadres of communist societies take advantage of new, liberal and institutionalized market, is known as "The surviving elite thesis" (Grossman 1989; Oi 1989; Shirk 1989, p. 340; Akos Rona-Tas 1994: Stark 1990, p. 389; Ren 1990, p. 141; Prybyla 1991; Staniszkis 1991, pp. 38-52; Kolosi 1991; Alexeev and Gaddy 1991; Burawoy and Krotov 1992, p. 34; McAuley 1992; Wank 1992; RonaTas 1995).

Main assumption of this approach is that old elite take advantage from the transitional process while they reproduce itself. Authors have based this position in two crucial arguments.

First, technocratic continuity, which emphasize that regime change, can happen only through experts that not only can contribute with the required experience on specific expertise field, but also with their education (Szalai 1990, p. 182). In his article "The First shall be last? Entrepreneurship and Communist Cadres in the Transition from Socialism" Akos Rona-Tas, points out that empirical comperative studies on post communist society stratification consider education as the most decisive factor on new post communist elite formation (Akos Rona-Tas 1994). Education helps old elite to adapt faster to the new system. The more educated and experienced people are, the better the chances that they will perform on the open market. In this view , education is combined with know how and connections that old elite posses as part of their inherited power, leading in this way to unmatched advantage against the new elite (Akos Rona-Tas 1994; Zagorski et al. 1984; Haller, Kolosi; Connor 1979; Matras 1980; Simkus 1981).

Secondly, the argument of power changing thesis that reflects the power accumulation during communist system phenomenon of old elite, which is translated in the open market economy as the greatest asset. In the "The Dynamics of the Breakthrough in Eastern Europe: The Polish Experience" article, Staniszkis elaborates the concept of "political 
capitalism" which describes the changing of communist regime as a necessity for the economies in transition. According to him, during the transition process to an open market economy, cadres benefit from their current positions in order to acquire for themselves enormous assets. Via informal channels, taking advantage from unsecure and quiescence situations, cadres manage state properties as they were their own private property. Thus, "using" also their personal network of connections and inside market information, this whole inherited valuable capital, was introduced with new entrepreneurs and corporate as the new open liberal system requires (1991).

This new political economic elite produces a serious of deformations in post communist societies, which not only create fertile ground for elite reproduction, but in several extreme circumstances gives life to vicious economic criminal cycles that destroy the pluralism and democratization process altogether. As a result, elite circulation is not viable and once again reproduction of same elite is reinforced.

Social inequality is one of the consequences that are a derivative of the correlation between market in transition and "resource usage" from old nomeklatura (Nee 1998). In its worse application this product encourages criminal activity. Most authors agree that the rate of collaboration between criminal networks, political and economic elite in post communist societies is considerably higher. This is attributable to lack of rule of law, monopolization of natural resources, high level of base corruption, overlapping of functionalities between political and economical elite since their functioning in society is not easily separated one from another (Vladimir Shl and Christopher VI and Boris Doktorov . 1999;Robert Lerner; Althea Nagai; and Stanley Rothman; 1996; Eric Carlton 1996).

Furthermore, in their empirical study "New Elite in Post Communist Eastern Europe "Vladimir Shl and Christopher VI and Boris Doktorov ,explain through theoretical concepts of rent seekers and rent givers, oligarchic post communist systems. The role of rent seekers is taken by economic elites, while the rent givers from the political elite. In exchange of financial electoral support, they assist economic elite via implementing friendly taxation law, monopoly- favourable laws, and the exchange goes on further until vicious financial circles are created. Thus political elite take a firm grasp on power and extend their political longevity by "using" public property and legislations in support of economic elite interest who invest large sums of cash for their re-election. (William Mitchell and Michael Manger 1991).The result of such interaction among rent seeker and rent givers does not foster a fair and constructive political and economical competition. (World Bank 1997; John Heller 1997).

The case study "Krysha" is one of the investigated examples that can explain the politico-economic criminal activity in post communist countries (more specifically in Russia and Ukraine). Krysha, which means "roof "is the figurative term of the phenomenon. It is used in order to explain how businesses are forced to hand more than $20 \%$ of their profits to criminal mafia gang members, in exchange for life protection. (Vladimir Shl and Christopher VI and Boris Doktorov, 1999).

Another impact is the creation of a dangerous society with aggravating unemployment, insecurity and most importantly a passive civil society, which does not trust political processes, is not represented and most of all does not play the role of counter elite. As a consequence, political elite does not feel any pressure of circulation by the new meritocratic political elite class. The last section tries to address the importance and shed light to understand the correlation between civil society, intellectuals and political elite in post communist countries.

\section{Civil society and intelligentsia}

Civil society is considered the catalyst of political elite circulation. In order for a society to give birth and space to healthy and functional democratic institutions, it needs foremost, to have an active and represented civil society. In the end, civil society plays active role in recruiting new political ridership ; encouraging political organization; motivating its citizens on how to face the political challanges (Mesharch W. Katusiimeh 2006; 103).

The stronger and more represented the civil society is, the more circulated the political elite will be. Among other criteria, the elite circulation is an indicator of open and pluralist democratic systems. Unfortunately, the majority of authors, point out that in post communist countries democracy and elite circulation are not functioning well because of the: (1) civil society 
involvement in political processes ; (2) civil society mistrust towards political reforms; (3) insufficient involvement of intelligntsia in politics (Graeme Grill 2002; Frane Adam and Matev. Tom.ič 2002; Mesharch W. Katusiimeh 2006;Vladimir Shl and Christopher VI and Boris Doktorov 1999).

The authors that analyze post communist elite through the concept of civil society and accept that these societies are characterized from an unorganized and unrepresented civil society, weak institutions and reproductive elite, distinguish two main categories.

Countries such as Hungary, Poland belong to the first category, where circulation of political elite phenomena is more evident, because of a more active civil society (Frane Adam and Matev. Tom.ič 2002). The whole changing regime process was dominated by the philosophy of political elite activity partnering with civil society. Old nomeklatura is transformed to an open and transparent political party in which members of civil society are integral and active participants. Summarizing it, political elite is characterized by the transparency and circulation of new blood within it.

On the contrary, the second category is characterized by a passive civil society and reproductive political elite. Old regime and nomeklatura transform themselves, creating this way the reproduction of the same people. Albania is a vivid example with the philosophy of building the new democratic regime, excluding the contribution of civil society. As a result the product is the creation of an oligarchic system (Graeme Grill 2002).

Oligarchy located in the politico - economic conditions of post- communist countries, as also explained in part on political elite marketization, produces vicious criminal networks, unemployment, and massive accumulation of capital by the political elite. All these factors have as a consequence the creation of a culture of distrust and inactivity of civil society towards political processes.

Mistrust and "lack of patience "towards political, economic and social reforms create situations in which change is considered unattainable. In these conditions of missing values, the influence of civil society upon political elites is reduced significantly. According to Sztompka, who analyzes the Polish post communist society , but also that of post-communist in general "culture of disbelief " prevents citizens from building constructive social, political and economic realities. Is this lack of trust and inactivity that allows political elites to use their raw power naked and not disguised (Piotr Sztompka.1989; 37 59). All this situation of insecurity is compounded if we bring into the picture a mosaic of laws and regulations from the past. The result is political confusion which allows the elite to hide under the pretention by claiming to represent the common good of public, being guardians of the law and the only instruments that can develop society. This kind of political reality disintegration and collapse of society delegitimize any approach which might be brought against the activity of the political elite, which is not challenged in its existence by any possible counter elite force, or strong civil society.

Another factor which explains the passivity of civil society is the inactivity of the intellectuals to organize it. The common reason to all post- communist societies referred by Alex Oushakine, in the article "Wiether the inteligencia " is the withdrawal from the moral basis which a distinctive feature for previous intellectuals . Common interests for universal and shared values, are replaced by interest groups, professional codes and identity of personal policies (Alex Oushakine 2009). Authors bring to the attention the fact that with system change, intellectual fallout from public activities played a major role in weakening the norms and cultural influence in this period. Dilution of norms, values and established practices is accompanied by the disappearance of the intellectuals as an autonomous group. More fragmented and diverse, new classes choose strategies of professional existence and patterns of cultural involvement which have little to do with intellectual class of late socialist. As a result, post - socialist societies seem more concerned with achieving socio - economic restructuring rather than ideological and cultural uniformity and the subsequent criticism towards the political processes that intellectuals have historically been known for. 
Fragmentation of the intellectual call and its cultural ethic does not mean it has lost value, just that the intellectuals and its values have become practically unfit for the new market order. The fragmentization of social inclusion and public responsibility influenced also the changing from the pedagogical cultural consumption to a hedonistic one. The activation of inteligencia in post communist societies, it is driven from the domination of interest groups.

Furthermore, Elena Gapova in her essay 'Conceptualizing gender, national and class in post -soviet Belarus, explains why intelligentsia is dominated in her activity by certain groups of interest. According to her, inteligencia has lost its moral, which means that in order to produce ideas and strategies it needs to be financed. Moral support of old regime is replaced by monetary support in post communist societies (Elena Gapova, 2004). As a result, the end product is by default designed not for the common good, but for certain interest. In this way, political elite does not face meaningful or discomforting challenges to its course and actions. This most often occurs when technocrats' mission is overlapped by the political elite interest. Thus, without inteligencia pressure, the level of reproduction is much higher than that of circulation (Szelenyi, Ivan/Szonja Szelenyi 1995. 619-627).

\section{Bibliography}

[1] Alex. Oushakine. 2009 , Wither the intelligentsia: the end of the moral elite in Eastern EuropeAuthor(s):: Studies in East European Thought, Vol. 61, No. 4, Wither the Intelligentsia: The End of the Moral Elite in Eastern Europe pp. 243-248

[2] Buchanan, Tollison, and Tullock. 1994. "Toward a Theory of the Rent Seeking Society; Anne Krueger, "Economists' Changing Perceptions of Government", in Comparative Economic Systems:Models and Cases, ed. Morris Bornstein ( Burr Ridge, III.: Irwin,), pp. 86-89.

[3] David Stark, 1992. "Path dependence and privatization strategies in East Central Europe," East European Politics and Societies 6: 17-51; and David Stark, "Recombinant property and East European capitalism," American Journal of Sociology.

[4] Diamandouros and Larrabee. 1996. Democratization in South-Eastern Europe ed. Bianchini Stefano and Schopflin George in State Building in the Balkans, Long Editore Ravenna, pp. 48-49

[5] Elena Gapova, 2004. 'Conceptualizing gender, nation and class in post soviet Belarues "

[6] (Carol Nechemias, K. Kuehnast eds.), Woodraw Wilson Center Press/Johns Hopkins University Press, 2004.

[7] Field L., George/Higley John/Burton G., Michael (1990), "A New Elite Framework for Political Sociology," Cahiers Vilfredo Pareto 28, 88, pp. 153-162

[8] Frane Adam / Matev. Tom.ič (2002). Elites, Democracy and Development in Post-Socialist Transition, Lubjana, 99-105

[9] Graeme Grill, 2000. The Dynamics of Democratization: Elites, Civil Society and the Transition Process.

[10] Graeme Grill, 2002. Democracy and post communism -Political change in the post communist world -New York, Routledge

[11] John Higley and Michael Burton , 1998. Elite settlements and Taming of Politics. Goverment and Opposition Blackwell Publishing vol. 33, no. 1

[12] Hankiss, E. (1990) East European Alternatives. Oxford University Press, Oxford. Staniszkis, J. (1991) The Dynamics of Breakthrough in Eastern Europe. University of California Press, Berkeley, Calif.

[13] Haller, Max, Tamas Kolosi, and Peter R6bert. 1990. "Social Mobility in Austria, Czechoslovakia, and Hungary." Pp. 153-97 in Class Structure in Europe: Neë Findings from East-West Comparisons of Social Structure and Mobility, edited by Max Haller. Armonk: M. E. Sharpe.

[14] Higley, J. (eds) .1990. Elites, Crises, and the Origins of Regimes. Roëman and Littlefield, Boulder, Colo, pp. 125-146. on, Neë York, 47.52. 
[15] James Buchanan 1980. "Rent Seeking and Profit Seeking", in Toward a Theory of the Rent Seeking Society, ed. James Buchanan, Robert Teleostan, and Gordian Bullock ( College Station: Texas A\&M University Press), p. 3.

[16] Kitschelt, Herbert ,1999. "Accounting for outcomes of Post-Communist Regime Change. Causal depth or shalloëness in rival explanations". Paper prepared for delivery at the 1999 Annual Meeting of the American Political Science Association, Atlanta, September 1-5, 1999

[17] Nee Victor. 1989. "A Theory of Market Transition: From Redistribution to Markets in State Socialism." American Sociological Revieë 54:663-81.

[18] Linz, J.and Stepan, A. (1996) Problems of Democratic Transition and Consolidation. Johns Hopkins University Press, Baltimore, Md.

[19] Serguei Alex. Oushakine, 2009. "Introduction: Wither the intelligentsia: the end of the moral elite in Eastern Europ Springer Science+Business Media B.V. 2009

[20] Staniszkis, Jadwiga. 1991. The Dynamics of the Breakthrough in Eastern Europe: The Polish Experience. Berkeley and Los Angeles: University of California Press.

[21] Pareto, Vilfredo (1997). Selections from the Work of Vilfredo Pareto, in: Eva Etzioni-Halevy (ed): Classes \& Elites in Democracy and Democratization, New York, 47.52.

[22] Piotr Sztompka, 1989. "Trust and Emerging Democracy", International Sociology 11: 37-62

[23] Vladimir Shl and Christopher VI and Boris Doktorov . (1999). The New Elite in Post-Communist Eastern Europe. Texas A\&M University Press

[24] Zag6rski, Krysztof, Rudolf Andorka, Nancy Brandon Tuma, and John W. Meyer. 1984. "Comparisons of Social Mobility in Different Socio-Economic Systems." Pp. 13-42 in International Comparative Research: Social Structures and Public Institutions in Eastern and Western Europe, edited by Manfred Niessen, Jules Peschar, and Chantal Kourilsky. Oxford: Pergamon

[25] Wasilewski, J. (1998) Hungary, Poland and Russia: the fate of Nomenklatura elites. In Dogan, M. and Higley, J. (eds) Elites, Crises, and the Origins oj Regimes. Roman and Littlefield, Boulder, Colo, pp. 147-167.

[26] William Mitchell and Michael Manger. 1996. "Economic Models of Interests Groups: An Introductory Survey", American Journal of Political Science 35 (1991): 525; Glenn Parker, Congress and Rent Seeking Society (Ann Arbor: University of Michigan Press,), p. 22.

[27] White, S. and Kryshtanovskaya, O. (1998) Russia: elite continuity and change. In Dogan, M. and

[28] World Bank, 1997. The State in a Changing World ( New York: Oxford University Press

[29] http://www.transparency.org/country\#ALB

[30] http://europa.eu/rapid/press-release_MEMO-13-574_en.htm

[31] https://www.freedomhouse.org/report/freedom-press/2013/albania\#.VLe8FNLF-Y8

[32] https://eudelegationalbania.files.wordpress.com/2014/10/memo-on-key-findings_eng.pdf 